\title{
Environmental Influences on South African Fish Catch: South Coast Transition
}

\author{
Mark R. Jury ${ }^{1,2}$ \\ ${ }^{1}$ Faculty of Science and Agriculture, University of Zululand, KwaDlangezwa 3886, South Africa \\ ${ }^{2}$ Physics Department, University of Puerto Rico, Mayaguez, PR 00681, USA
}

Correspondence should be addressed to Mark R. Jury, mark.jury@upr.edu

Received 12 May 2011; Revised 26 November 2011; Accepted 29 November 2011

Academic Editor: Robert Frouin

Copyright (C 2011 Mark R. Jury. This is an open access article distributed under the Creative Commons Attribution License, which permits unrestricted use, distribution, and reproduction in any medium, provided the original work is properly cited.

\begin{abstract}
This study considers environmental factors influencing aggregate fish catch in the South Coast transition of South Africa. The environmental forcing is studied via (i) seasonal analysis of SeaWifs chlorophyll and related variables, (ii) composite analysis of atmospheric and oceanographic reanalysis data, (iii) statistical analysis of annual FAO fish catch with climatic indices, and (iv) analysis of depth-latitude hydrographic sections over the shelf (33-36S, 22-26E). In years of higher fish catch there is a northward shift of the subtropical anticyclones and upwelling that is partially related to Pacific El Nino. Westerly troughs skirt the Agulhas Bank creating onshore Ekman transport. Higher sea surface height inshore, and cooler sea temperatures and lower salinity offshore induce a gradient that weakens the Agulhas Current. These environmental conditions favour the southeastward migration of juvenile fish from west to south coast. A multivariate model of aggregate fish stocks, using four environmental variables: salinity and zonal currents in the Agulhas Current, sea temperature in the Agulhas source region, and geopotential height over the Cape, accounts for $53 \%$ of variance at $0-1$ year lead. Freshening of the boundary current is a factor influencing aggregate fish catch in the South Coast transition.
\end{abstract}

\section{Introduction}

Marine fish catch fluctuates in relation to human pressure, climatic conditions, and physiological requirements [1-10]. Long-term records on annual catch from the Food and Agricultural Organization $[11,12]$ exhibit quasidecadal cycles often with short bursts of high catch interspersed with longer quiescent periods [13-17]. Although fisheries often show climate dependence, the linkages are indirect because of complex feedbacks, lags between fishing effort and natural production, and weakness of the data $[18,19]$.

Retrospective studies that account for slow variations of the ocean and the life history and migration patterns of the fish have been conducted in the past 50 years using physical oceanographic fields $[20,21]$. The alternation of sardine and anchovy landings $[1,22]$ has been attributed to environmental conditions that affect spawning and feeding location [23-25]. Because of the worldwide extent and quasidecadal time scale of fishery fluctuations, global oceanatmosphere coupling has been proposed as a driver [26] through features such as the Pacific decadal oscillation (PDO), the North Atlantic oscillation (NAO) [27, 28], and the El Niño southern oscillation (ENSO) [21, 29, 30]. Resolving environmental influences on fisheries will contribute to better projections and management of fish stock fluctuations. Following from this discussion, key questions include: to what extent are regional fisheries affected by the surrounding environmental conditions? Are environmental factors within the catch region/during the catch year more important than remote/precursor teleconnections? Which atmosphere/ocean elements are most influential?

The marine fish catch along the southern tip of Africa (Figure 1) is comprised of short-lived shelf-zone pelagic and longer-lived deep-water species. Much is known about the region's oceanography [31] characterized by seasonal upwelling and abundant populations of sardine and anchovy. The fishery responds to the annual cycle [5] anchovy spawn on the western Agulhas Bank in early summer when high wind speeds are prevalent, while sardines spawn over a broader season and area $[32,33]$. Spawning over the eastern 


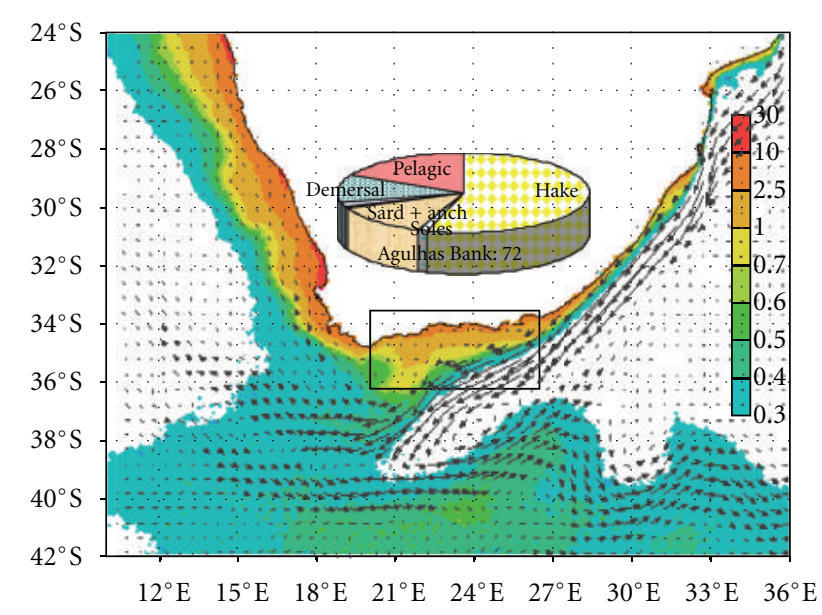

FIgURE 1: 10-year mean Seawifs chlorophyll content $\left(\mathrm{mg} \mathrm{m}^{-3}\right)$ and 30-year mean 0-200 $\mathrm{m}$ current vectors from SODA2.4. FAO fish catch pie chart; square is Agulhas Bank catch area; largest vector is $1 \mathrm{~m} / \mathrm{s}$.

Agulhas Bank can result in losses by strong currents. Success rates are highest when shelf temperatures are $16-19^{\circ} \mathrm{C}$. Eggs are transported from the Agulhas Bank to the St Helena Bay nursery area (chlorophyll max., Figure 1) by frontal currents [34]. Nursery area conditions are also important: upwelling is needed to maintain primary productivity, but not so much that larvae are exported. Juveniles then migrate back to the Agulhas Bank for recruitment, following various paths southeastward along the shelf. Roy et al. [35] suggest that the pelagic fishery shifted eastward after 1995 due to cooling over the shelf from enhanced easterly winds and seasonal upwelling. Here an alternative hypothesis is explored that the fishery is modulated by changes in the boundary current [36]; specifically, when the Agulhas Current is cool, fresh, and slow and westerly winds produce onshore Ekman transport, larvae retention and juvenile recruitment are favoured. With ocean-atmosphere reanalyses and historical catch information this hypothesis is tested for the Agulhas Bank. Section 2 covers the data and methods, while Section 3 presents the results divided into seasonal and fishery variability, large-scale forcing, local conditions, and climatic change. Section 4 provides conclusions and some recommendations.

\section{Data and Methods}

This study considers oceanic and atmospheric variability at annual time scales around Southern Africa (0-40S, 4-52E), the upstream Agulhas Current, and the Agulhas Bank (3336S, 20-28E, Figure 1). The methods seek to understand what environmental conditions influence fish catch, in addition to the effects of abundance, management, and effort. Annual fish catch statistics in the period 1976-2006 are drawn from the FAO fisheries data base. The major species oscillate together as indicated by cross-correlations between an aggregate fish index and the individual species: hake comprising half the catch has $r=+0.43$, pelagic comprising $17 \% r=+0.26$, sardines and anchovy comprising $12 \%$ $r=+0.85$, and demersal comprising $12 \% r=+0.38$, where $r>0.30$ is significant at $90 \%$ confidence for $N=30$. The sardine and anchovy catch has risen since 1998, while the demersal fishery has declined. Hake remained steady, and the pelagic catch (including sardine and anchovy before 1998) tends to oscillate. Since the various fisheries fluctuate together and details of individual species are uncertain in the early years, an aggregate fish catch index is developed for the Agulhas Bank. The annual fish catch is divided by the normalized population as a way of accounting for increasing fishing effort. Analyses were also made per species, but these support the aggregate results and were not further considered.

Atmospheric conditions are represented primarily by the National Center for Environmental Prediction (NCEP) reanalysis product [37]. These $2^{\circ}$ gridded fields are based on surface ship and coastal data, optimally interpolated using a numerical weather prediction model and enhanced by satellite remote sensing since 1979. Because the south coast of South Africa has a busy shipping lane, the comprehensive ocean atmosphere data set (COADS) is used for local wind time series. With the ocean affected by fresh water inputs from the land and atmosphere, $1^{\circ}$ gridded rainfall analyses from the Global Precipitation Climatology Project (GPCP) are considered that involve gauges over land and satellite estimates since 1979. River run-off data are extracted from the South African hydrological services for the Agulhasfacing coast, including the Tugela River at 29S.

The ocean environment is described by the SODAv2.4 reanalysis product of the University of Maryland at $0.5^{\circ}$ horizontal and $\sim 30 \mathrm{~m}$ vertical resolution [38]. These make use of hydrographic data (from SADCO and GTS), optimally interpolated using a numerical ocean model that employs European Community Medium-range Forecast (ECMWF) wind stress and surface fluxes, satellite thermometry since 1979, and satellite altimetry since 1985. A principal component analysis (PCA) was made to determine the dominant spatial clusters and detrended time scores over the period 1976-2006 for 0-200 m depth-averaged temperature, salinity, currents, vertical motion, and sea surface height in the southern African domain. The top three PCA modes were retained, and their annual time scores were cross-correlated with the FAO fish catch and other climatic indices. Because of the potential ambiguities generated by PCA, environmental time series were extracted for smaller domains, averaged over the Agulhas Current (26-33S, 29-35E) and the Agulhas Bank for comparison with the catch statistics. With the advent of SeaWifs chlorophyll estimates in 1997 that reflect primary productivity [39], an analysis of the seasonal cycle over the Agulhas Bank was done, and comparisons were made with the SODA2.4 ocean reanalysis variables, COADS winds, ECMWF wind stress, and GPCP rainfall. The analysis reveals seasonal amplitudes and processes underlying the Agulhas Bank shelf hydrography and biochemical productivity.

To understand the spatial pattern favoring fish catch, the atmosphere and ocean reanalysis data were compositeaveraged to produce high minus low $(\mathrm{H}-\mathrm{L})$ catch fields. These were done as maps and 0-600 $\mathrm{m}$ depth sections south of the Agulhas Bank in the longitudes 22-26E. To construct 


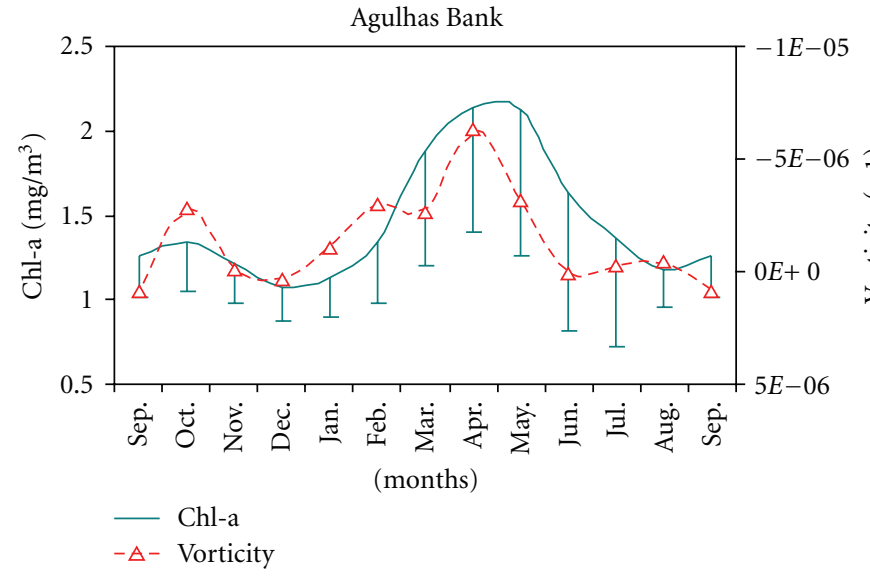

(a)

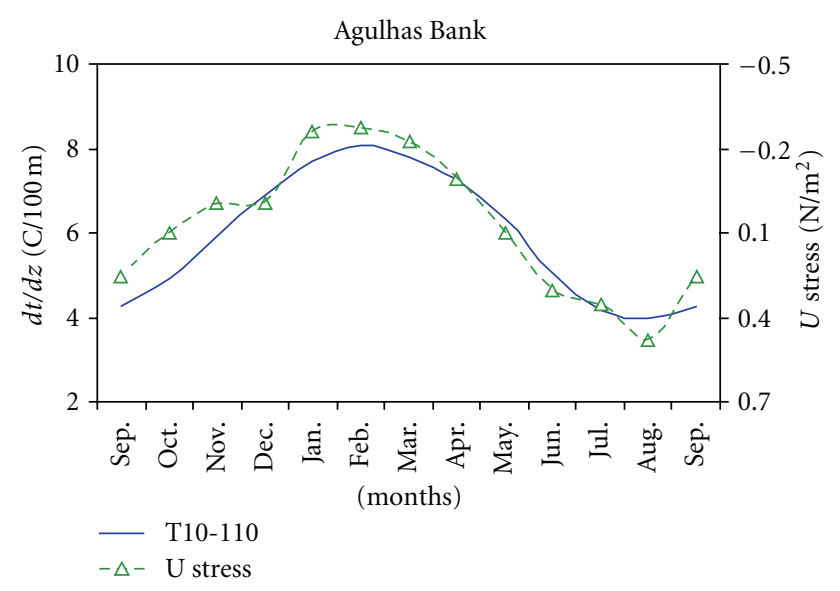

(b)

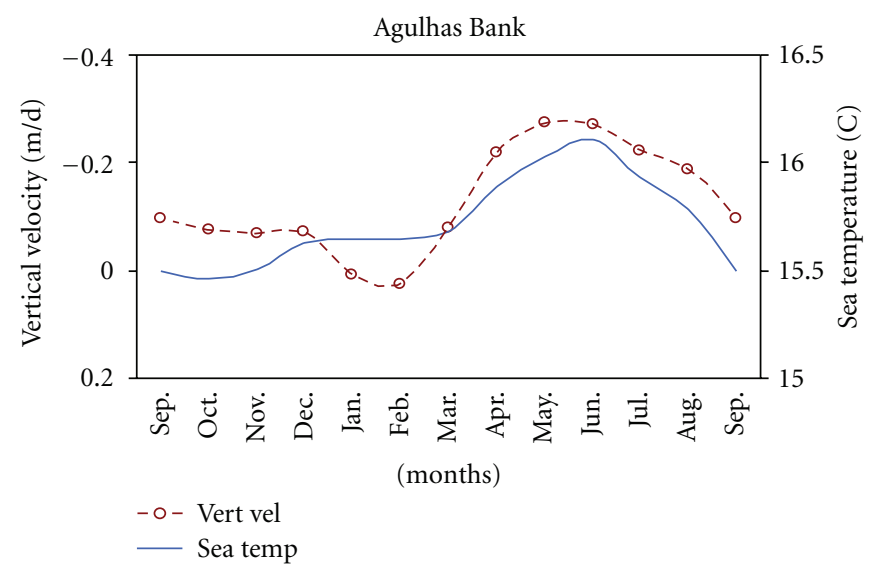

(c)

FIgURE 2: Agulhas Bank area-averaged annual cycle 1997-2007 for (a) SeaWifs mean chlorophyll, its standard deviation (bars), and wind vorticity (cyclonic $<0$ ), (b) temperature stratification and ECMWF zonal wind stress, and (c) 0-200 m averaged sea temperature and vertical velocity ( up $>0$ ). Some scales are inverted for comparison.

the composite, the catch record was divided into years of high and low catch in each 6-7-year cycle: 1979, 1985, 1992, 1997, 2005; 1977, 1981, 1988, 1995, 1999. Two domains were mapped: large-scale: 0-50S, 10W-52E and local: 31-38S, 16$28 \mathrm{E}$. Contrasts between the pattern of years with high and low catch were analyzed by field subtraction, and differences were evaluated for: SST, $200 \mathrm{hPa}$ upper wind, GPCP rainfall, ECMWF wind stress, $0-200 \mathrm{~m}$ depth-averaged temperature, salinity, currents and $0-500 \mathrm{~m}$ vertical motion. Supplementary analyses were made for seasonal periods to understand how the environmental signals vary from summer to winter. Composite $\mathrm{H}$-L differences exceeding one standard deviation are interpreted as significant.

The statistical analysis explores cycles in the fish catch using wavelet spectral methods [40]. The annual atmospheric and oceanic data averaged over the Agulhas Current and Agulhas Bank, the PCA mode time scores, and global climate indices: PDO, NAO, ENSO (Nino3 SST), and river run-off were compared with the annual fish catch time series to determine relationships. Pairwise cross-correlations were evaluated, and a two-year period: catch year + previous (0-1 yr lead) was found to be optimal. Using a stepwise regression procedure to insert successively influential (normalized) environmental variables, a multivariate model was formulated to account for fluctuations in aggregate fish catch. After adjustment for multiple predictors, 26 degrees of freedom requires $r>0.32$ for significance at 90\% confidence.

\section{Results}

3.1. Ocean Colour and Fish Catch Variability. The seasonal cycle of SeaWifs chlorophyll is shown in Figure 2(a). Primary production peaks during the autumn months March-May with cyclonic wind vorticity (curl). Wind stress is favourable for upwelling $(U<0)$ in January-March (Figure 2(b)), yet the surface layer is stratified by high solar radiation. Marked downwelling and warmer sea temperatures are experienced in May-June (Figure 2(c)) as westerly winds sweep over the area $[41,42]$ inhibiting phytoplankton blooms. There is a weak secondary peak in chlorophyll concentration in September-October, and a broad minimum from November to February (Figure 2(a)). As in most of the subtropics, productivity is confined to the shelf (cf. Figure 1). In the Agulhas Bank, the area of high chlorophyll widens toward the 
TABle 1: Pairwise cross-correlation values of Agulhas Bank environmental variables and Chlorophyll for seasonal (upper) and anomaly values in the period 1997-2007. Bold values are significant at 95\% confidence. +2 refers to Chl-a lagging two months. Values near zero are omitted.

\begin{tabular}{|c|c|c|c|c|c|c|c|}
\hline Seasonal & $U$ stress & $U$ current & $d T / d z$ & Wind curl & Vert. motion & Sea temp & Salinity \\
\hline$U$ current & 0.71 & & & & $N=12$ & & \\
\hline$d T / d z$ & -0.95 & -0.56 & & & & & \\
\hline Wind curl & 0.47 & & -0.51 & & & & \\
\hline Vert. motion & -0.66 & -0.90 & 0.49 & & & & \\
\hline Sea temp & 0.33 & 0.83 & & & -0.83 & & \\
\hline Salinity & 0.37 & 0.43 & & 0.31 & & 0.46 & \\
\hline Chl-a & & 0.45 & & -0.72 & -0.58 & 0.59 & \\
\hline Chl-a+2 & -0.75 & -0.32 & 0.81 & -0.44 & 0.47 & & \\
\hline Anomalies & $U$ stress & $U$ current & $d T / d z$ & Wind curl & Vert. motion & Sea temp & Salinity \\
\hline$U$ current & & & & & $N=120$ & & \\
\hline$d T / d z$ & & 0.30 & & & & & \\
\hline \multicolumn{8}{|l|}{ Wind curl } \\
\hline Vert. motion & & 0.11 & -0.25 & -0.16 & & & \\
\hline Sea temp & 0.07 & & & 0.21 & -0.19 & & \\
\hline Salinity & & 0.12 & -0.31 & & 0.14 & 0.31 & \\
\hline Chl-a & & & -0.20 & & & -0.21 & -0.13 \\
\hline Chl-a+2 & & & -0.09 & & 0.25 & & -0.16 \\
\hline
\end{tabular}

west with the axis of the Agulhas Current forming the outer edge. Cross-correlations of environmental variables (Table 1) indicate that spells of easterly winds induce vertical uplift and cooler fresher conditions, but simultaneous associations with chlorophyll are weak. When chlorophyll is lagged by 2 months, the relationship with vertical motion strengthens. Agulhas Bank shelf waters require stratification following upwelling to generate higher primary productivity. Fluctuations of chlorophyll are small in the food-poor, spring, and summer season and greatest in autumn and tend to follow the trend of mean values (cf. Figure 2(a)).

In Figure 3(a) the time series of FAO marine fish catch in the Agulhas Bank area is presented. Although the annual time series is normalized by population, a 2nd-order rising trend remains that accounts for $42 \%$ of variance. The increase in fish catch is attributed to a southward shift of the anticyclonic wind belt and more frequent upwelling favourable winds [35], an issue that is investigated below. There is a clear cycle, confirmed by wavelet spectral analysis to be significant (Figure 3(b)): 6 years in the early part of the record, lengthening to 7 years toward the end. The amplitude of the cycle also grows. In the following sections, the regional and local environmental factors that contribute to changes in Agulhas Bank fish catch are explored.

3.2. Large-Scale Influences. The PCA of ocean reanalysis fields in the South Africa domain reveals a number of distinct patterns, and those significantly correlated with the catch index are described. Figure 4 includes depth-averaged temperature mode-1, salinity mode-1, and atmospheric geopotential height mode-3. The patterns and temporal relationships suggest that cooling and freshening of Agulhas source waters at 0-1 year lead time promote higher fish catch. The mean currents that connect the source waters in the northern Mozambique Channel to the Agulhas Bank are such that it would take a few months for the water mass to arrive. The upper atmospheric geopotential PCA mode-3 pattern and its temporal correlation indicate that lower pressure over southern Africa associates with higher fish catch. The PCA time scores exhibit spectral energy in the range of 3-11 years. No single variable matches fish catch, so multivariate analysis is explored (cf. Section 4).

Composite high minus low catch $(\mathrm{H}-\mathrm{L})$ atmospheric reanalysis and SST maps are given in Figure 5. A remote signal is found in southern Angola waters. The Cape Frio upwelling plume is colder and extends further north than usual before and during years with high fish catch over the Agulhas Bank. SST differences are $-1.2 \mathrm{C}$ around 15S, 10E (Figure 5(a)). More vigorous coastal upwelling in the southeast Atlantic cold tongue is related to an equatorwarddisplaced subtropical anticyclone. In the upper atmosphere, $200 \mathrm{hPa}$ wind differences are from the west in the tropics and from the east over the SW Indian Ocean (Figure 5(b)). These wind patterns are consistent with Pacific El Nino [43-45] that bring dry weather to South Africa, as seen in the rainfall composite map (Figure 5(c)). The zone of reduced rainfall stretches from Angola to the Agulhas Current, causing Tugela River run-off to decline $(r=-0.44$ with respect to catch, cf. Table 2). Cool SST in the east Atlantic (cf. Figure 5(a)) often precedes Pacific El Nino. The near surface geopotential height map indicates the presence of a low/high pattern in the midlatitudes (L: 50S, 10E/H: 45S, 55E, Figure 5(d)). Analysis of fields at different lags indicates that higher pressure in the south Indian Ocean "blocks" atmospheric troughs over South Africa. Composite easterly winds from south of Madagascar meet westerly winds over the eastern Agulhas Bank. The regional environment thus exhibits key signals in composite analysis. 


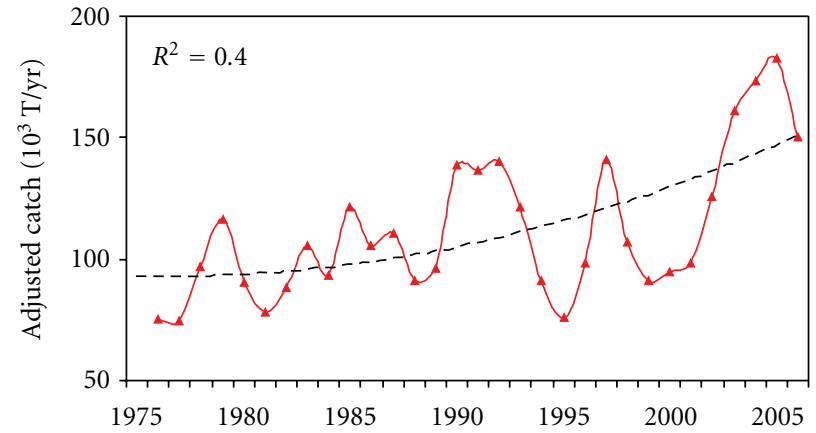

(a)

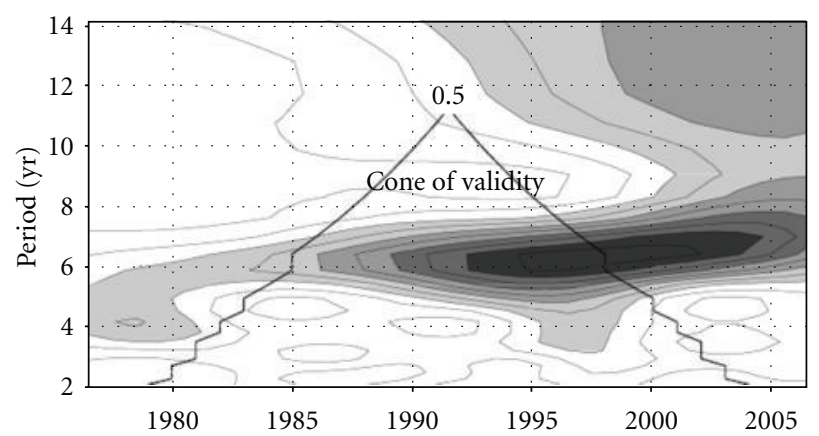

(b)

Figure 3: (a) Agulhas Bank population-adjusted aggregate fish catch index and 2nd-order trend, (b) wavelet spectra contoured at 0.1 significance intervals; darkest shading $>0.9$ illustrates 6-7 year cycle.

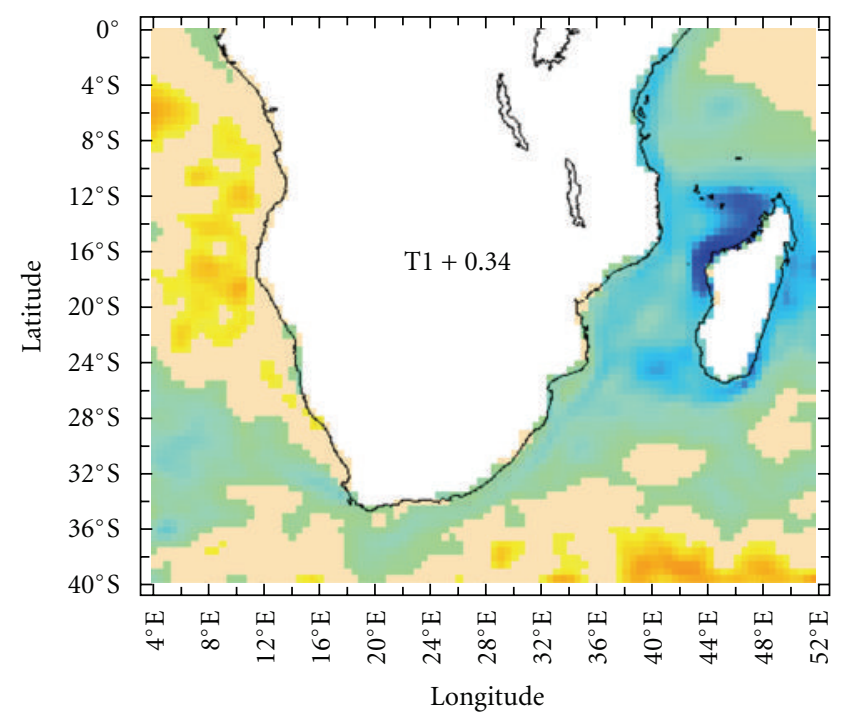

(a)

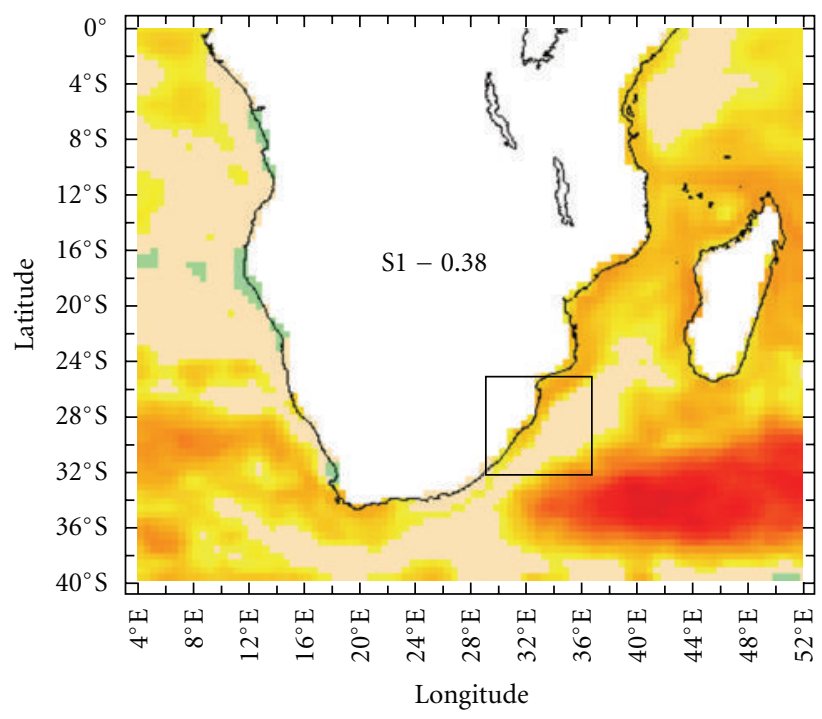

(b)

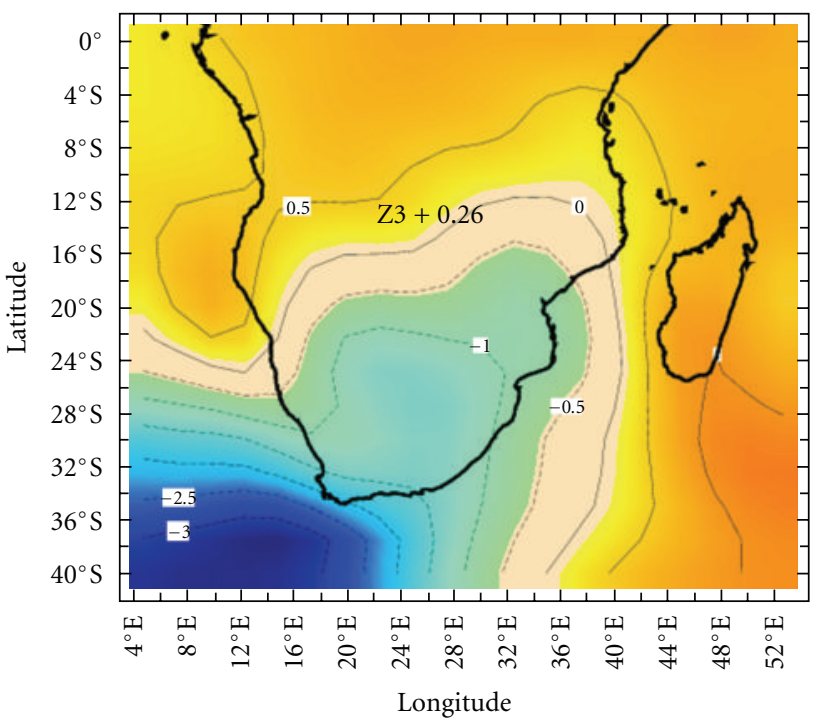

(c)

FIGURE 4: PCA loading maps for key environmental variables relating to Agulhas Bank fish catch: (a) SODA2.4 0-200 m temperature mode-1, (b) salinity mode-1, and (c) atmospheric geopotential height mode-3. Ocean fields are 0-200 m depth averaged, atmospheric field 0-1.5 km height averaged. Box in (b) is the Agulhas Current region. 


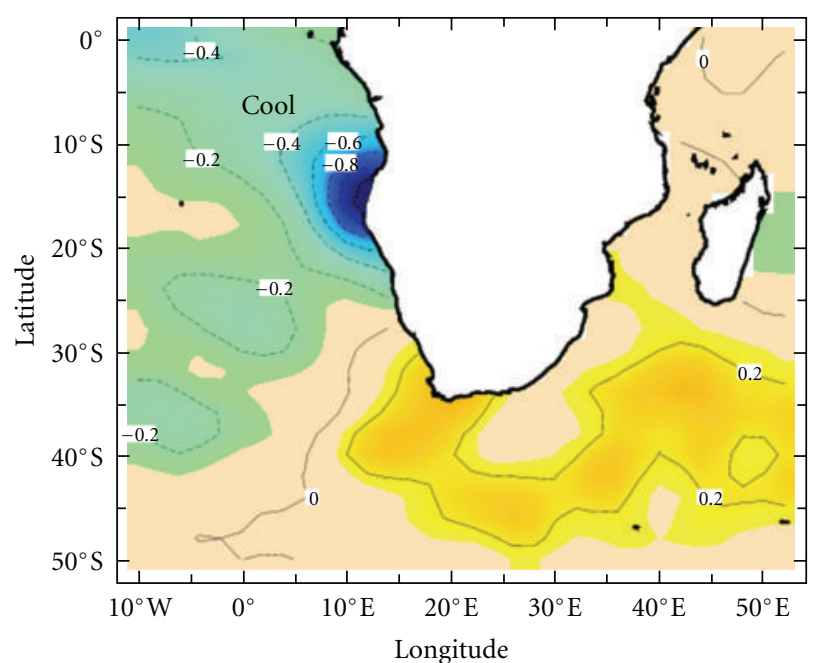

(a)

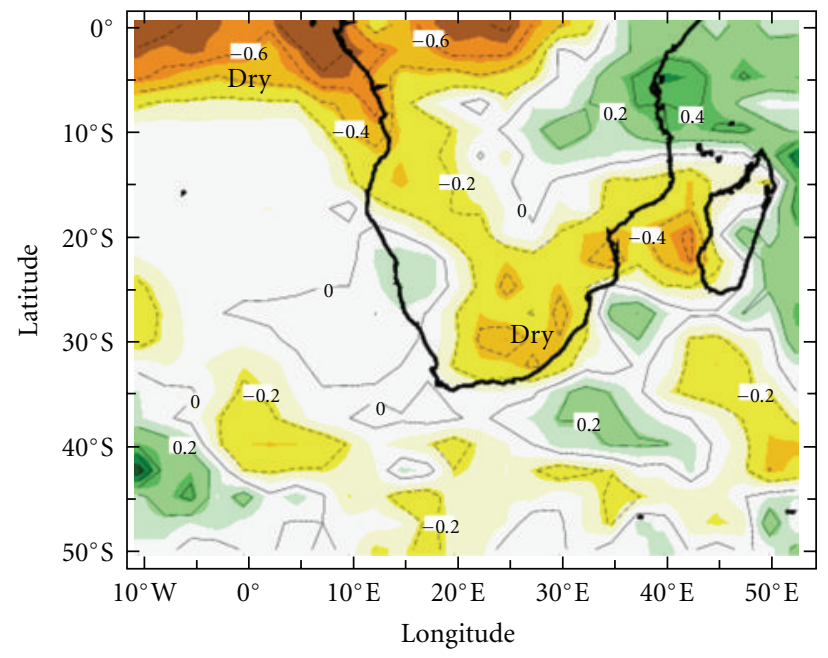

(c)

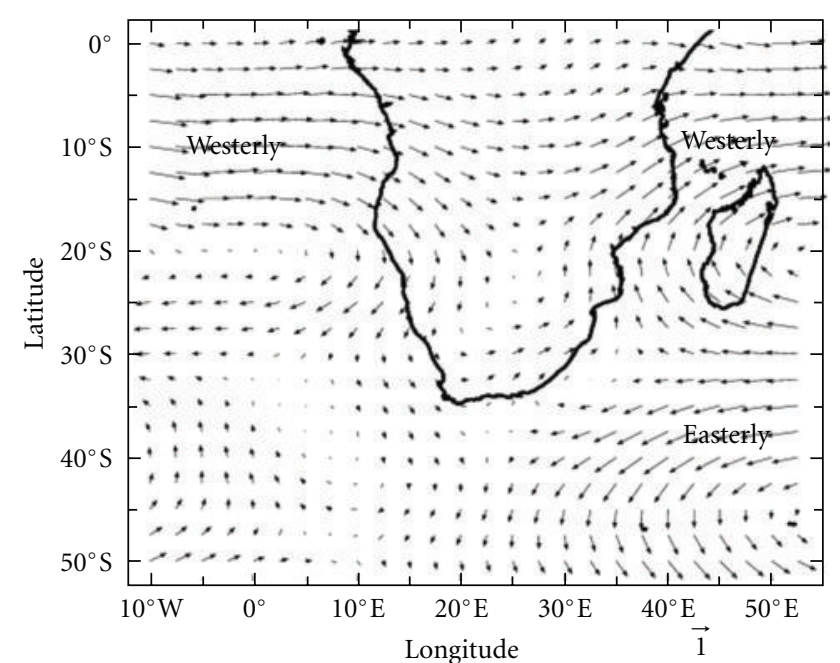

(b)

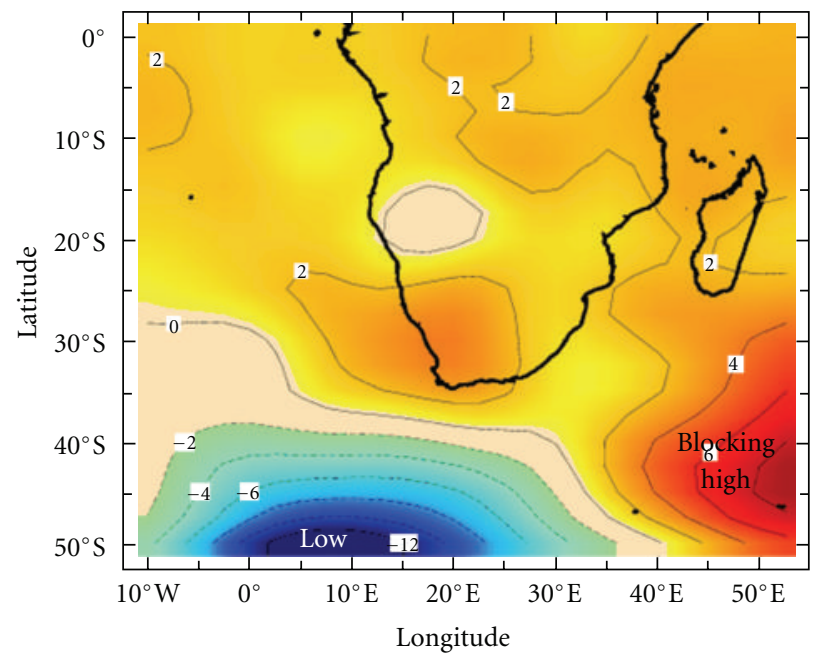

(d)

Figure 5: Composite atmospheric reanalysis fields for $\mathrm{H}-\mathrm{L}$ catch years: (a) NOAA SST $\left({ }^{\circ} \mathrm{C}\right)$, (b) NCEP upper $200 \mathrm{hPa}$ wind $(\mathrm{m} / \mathrm{s})$, (c) GPCP satellite-gauge rainfall (mm/day), and (d) NCEP 1000-850 hPa geopotential height (m). Cape Frio upwelling extends northward, and the weather over South Africa is dry.

Time series in the upstream Agulhas Current region (2633S, 29-35E) exhibits correlations with fish catch: salinity $r=-0.55$, followed by rainfall -0.40 , and zonal currents +0.37 (Table 2). Hence lower salinity and a weakened Agulhas Current benefit the fisheries. Reduced rainfall is associated with higher fish catch and is consistent with the presence of low pressure over the Cape (cf. Figure 4(c)), increased westerly winds, and reduced river run-off along the east coast.

3.3. Composite Shelf Conditions. Ocean reanalysis H-L composites maps and sections over the Agulhas Bank are given in Figures 6 and 7, respectively. The maps cover the recruitment pathway and include the west coast nursery area. There is a significant westerly wind difference over the Agulhas Bank, and offshore winds are evident over the west coast (Figure 6(a)). Ekman transport tends to be poleward on the west coast and onshore along the south coast. Thus juvenile fish seeking recruitment are "helped" by favourable winds and currents. Westerly wind differences are consistent with El Nino [46, 47]; Pacific SST $r=+.29$ with respect to fish catch (cf. Table 2). The onshore Ekman transport lifts the sea surface height nearshore (Figure 6(d)) inducing eastward current differences over the shelf edge 35-37S, 2026E (Figure 6(b)). Although $\mathrm{H}-\mathrm{L}$ wind differences are easterly over the Agulhas Bank during summer (not shown) in agreement with Roy et al. [35], the annual composite (Figure 6(a)) indicates that westerly winds prevail.

The composite $\mathrm{H}-\mathrm{L}$ temperature and sea surface height patterns indicate that coastal upwelling is reduced (Figures 6(c) and 6(d)), while cooler waters are found offshore. This gradient works against the mean state and weakens the Agulhas Current. Salinity is neutral in the coastal zone, but there is a fresh signal offshore (Figure 6(e)). These features are analyzed in vertical section in Figures $7(\mathrm{a})$ and 7(b). Cooler temperatures $(-1.2 \mathrm{C}$ from $100-300 \mathrm{~m})$ and 


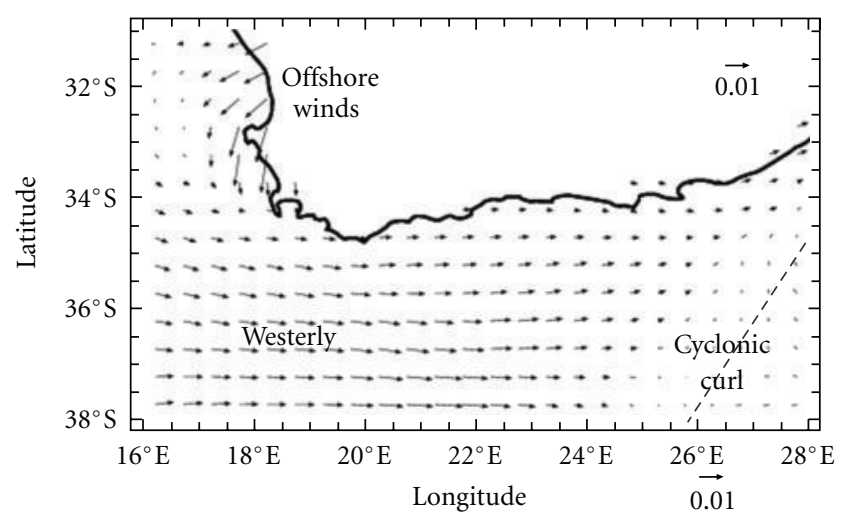

(a)

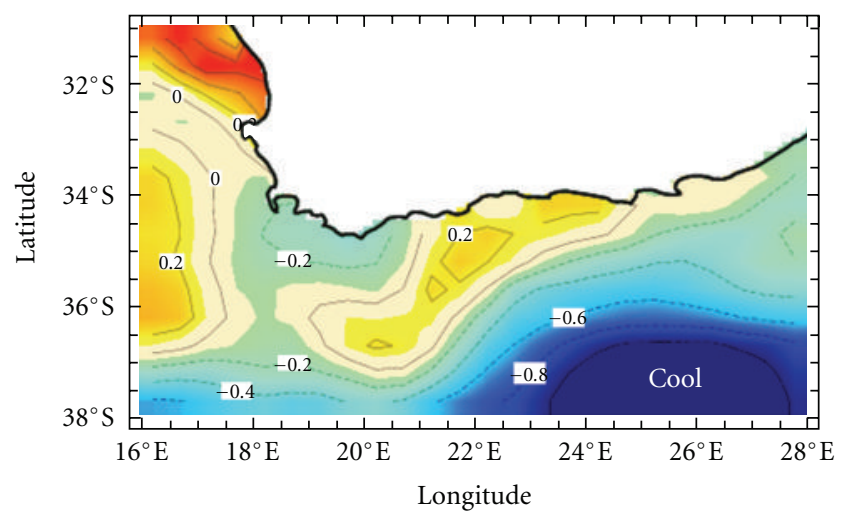

(c)

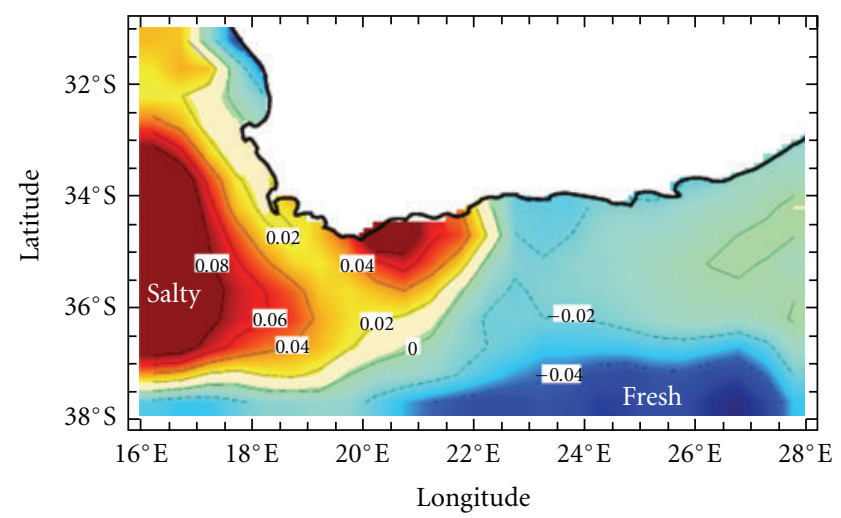

(e)

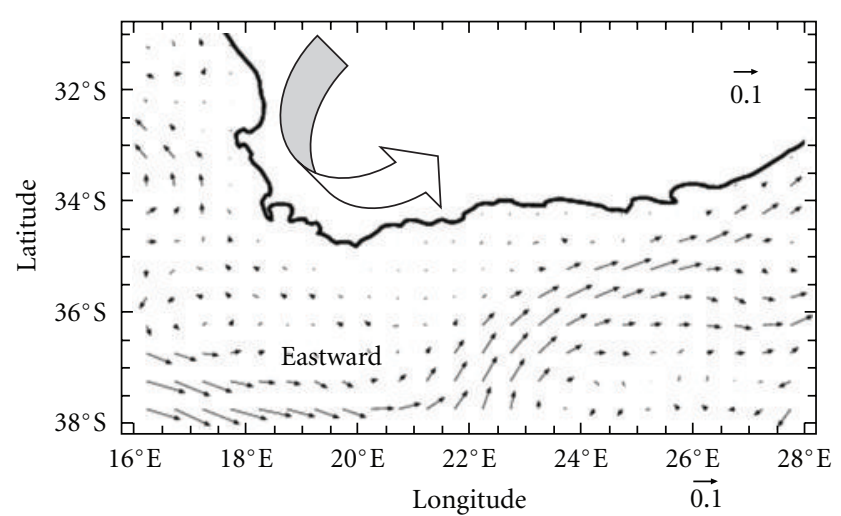

(b)

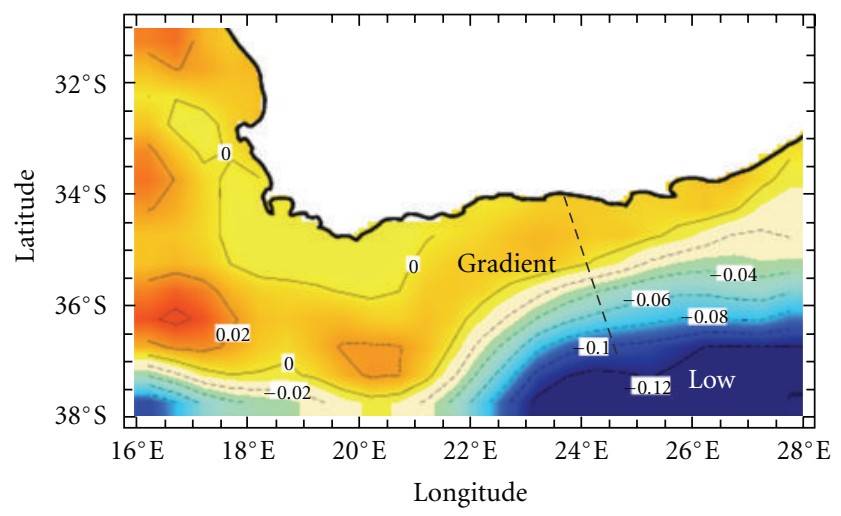

(d)

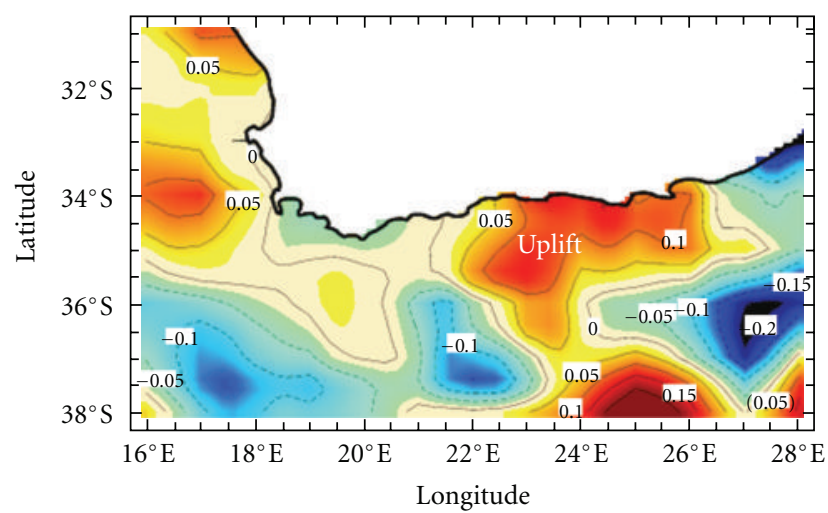

(f)

FIgURE 6: Composite SODA2.4 ocean reanalysis fields for H - L catch years: (a) wind stress, (b) 0-200 m currents, (c) 0-200 m temperature, (d) sea surface height, (e) 0-200 m salinity, (f) 0-500 m vertical motion. Note eastward current differences over the Agulhas Bank related to the sea surface height gradient (d); vertical sections are constructed along its axis in Figure 7.

lower salinity $\left(-0.12 \mathrm{~g} \mathrm{~kg}^{-1}\right.$ from $\left.250-450 \mathrm{~m}\right)$ are evident beyond the shelf edge (36S). There is anomalous onshore flow and vertical uplift ( $>0.5 \mathrm{~m} /$ day) on the shelf (35S, $25 \mathrm{E}$ ) in the 200-600 m layer (Figures 6(f) and 7(c)), despite the anomalous westerly winds and onshore Ekman transport near the surface. The uplift appears related to anomalous cyclonic wind stress curl created by westerlies on the Agulhas Bank meeting easterlies from the SW Indian Ocean (Figure 6(a)). Weakening of the Agulhas Current is most evident in the $0-200 \mathrm{~m}$ layer around 36S (Figure $7(\mathrm{~d})$ ).
Prevailing before and during high catch years, these features favour the migration of pelagic species from west to south coast.

\section{Discussion}

The relative role of local and remote atmosphere and ocean forcing is explored by multivariate stepwise regression of key environmental variables onto the aggregate catch index. The scatterplot is given in Figure 8 and the statistical summary 


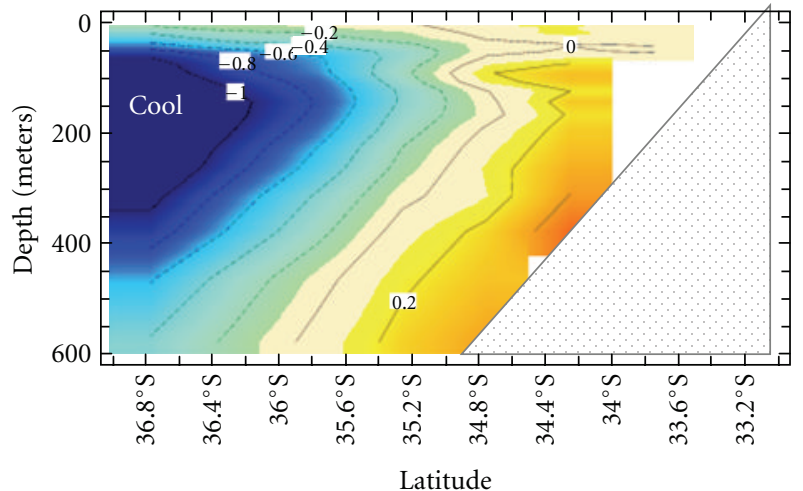

(a)

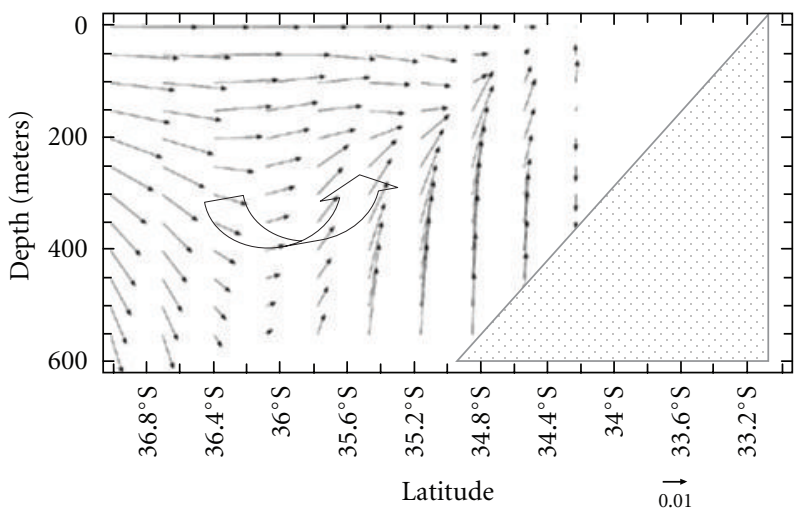

(c)

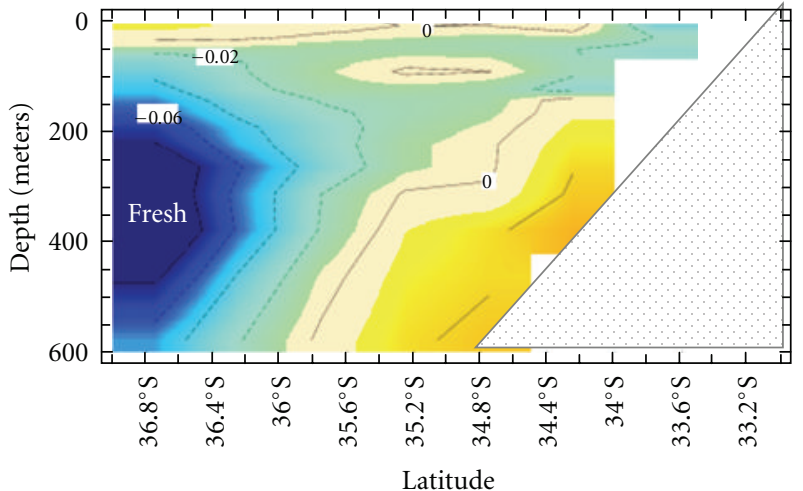

(b)

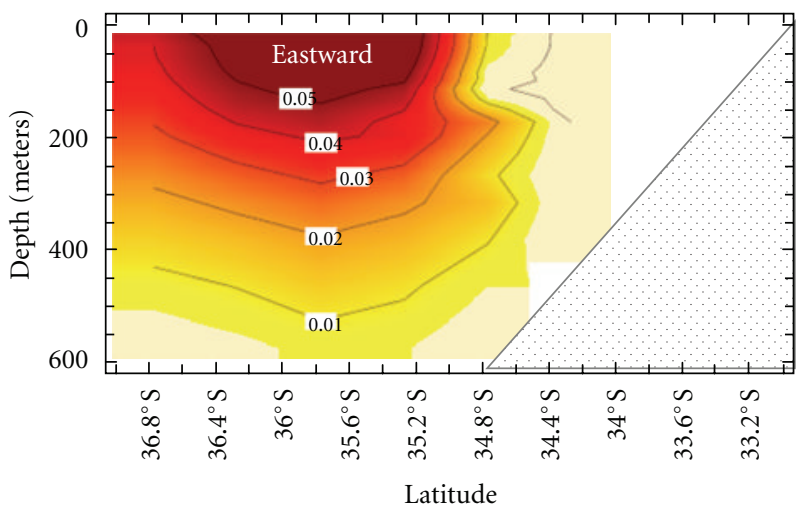

(d)

Figure 7: Composite H - L SODA2.4 ocean reanalysis N-S sections over the 0-600 m layer from 33-37S, averaged 22-26E: (a) temperature $\left({ }^{\circ} \mathrm{C}\right)$, (b) salinity $\left(\mathrm{g} \mathrm{kg}^{-1}\right)$, (c) meridional current and vertical motion $\left(\mathrm{m} \mathrm{s}^{-1}\right)$, (d) zonal currents $\left(\mathrm{m} \mathrm{s}^{-1}\right)$. View is to west with coast on the right represented by shading.

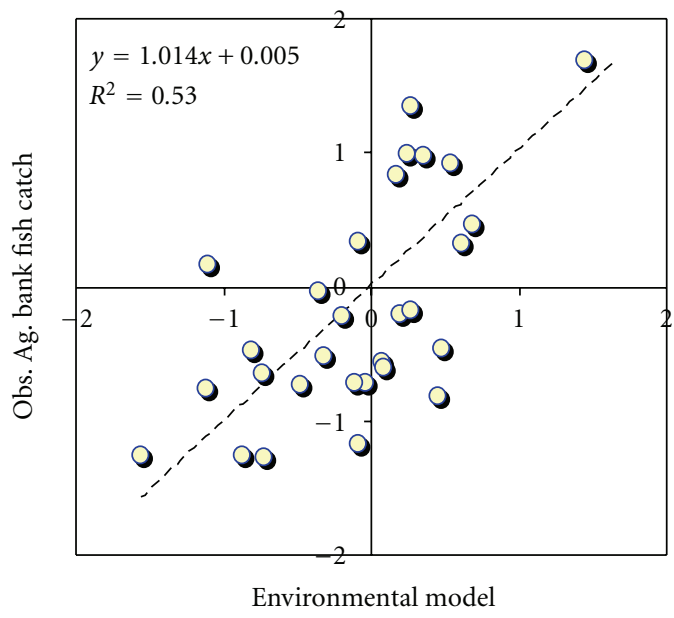

Figure 8: Multivariate regression of environmental variables onto aggregate fish catch at $0-1$ yr lead time.

in Table 2. Two PCA time scores and two area-averaged time series are selected in stepwise regression to account for 53\% of variance at 0-1 year lead. An important variable is salinity in the upstream Agulhas Current (coefficient -0.53), followed by temperature mode-1 $(+0.47)$, upper atmospheric geopotential height mode-3 $(+0.36)$, and upstream Agulhas zonal current $(+0.34)$. This mix of "predictors" has wavelet spectral energy of $4 \mathrm{yr}$ in the 1976-1994 period and $6 \mathrm{yr}$ since 1995 and a weak upward trend contributed by declining salinity and currents in the Agulhas Current. The scatterplot is relatively symmetrical, so the environmental forcing that induces high catch is opposed for low catch, albeit with half the variance still unexplained.

The ocean-atmosphere environment around the Agulhas Bank has been analyzed in the context of aggregate fish catch, with a focus on contrasts between high and low years. There is an equatorward shift of the atmospheric circulation and upwelling in high catch years. Westerly troughs skirt the Agulhas Bank around a midlatitude low-pressure anomaly (cf. Figure 5(d)) that suppresses rainfall and river discharges over South Africa. The anomalous wind and current regime (cf. Figures 6(a) and 6(b)) favours the migration of juvenile fish from west to south coast, with a cycle of 6-7 years. Higher sea surface height inshore and cool fresh waters offshore induce a gradient that weakens the Agulhas Current. The composite difference maps reveal links between Agulhas Bank fish catch and ocean climate at 0-1 year lead.

A multivariate regression model used regional environmental variables to "hindcast fit" aggregate fish catch and suggested upstream conditions in the Agulhas Current as 
TABle 2: Pairwise cross-correlations (upper) and multivariate statistics at 0-1 yr lead time. Variables are: Sal1: mode-1 salinity 0$200 \mathrm{~m}$, Temp1: mode-1 temperature 0-200 m, Z3: mode-3 $850 \mathrm{hPa}$ geopotential height, Rain: rainfall over South Africa and Agulhas Current, SALa: Salinity 0-200 m Agulhas Current, SSHa: sea surface height Agulhas Current, Ua: zonal component of Agulhas Current, Va: meridional component of Agulhas Current, Tugl: Tugela River outflow, Nino3: central Pacific SST. Most influential variable is Salinity in the Agulhas Current (SAL a).

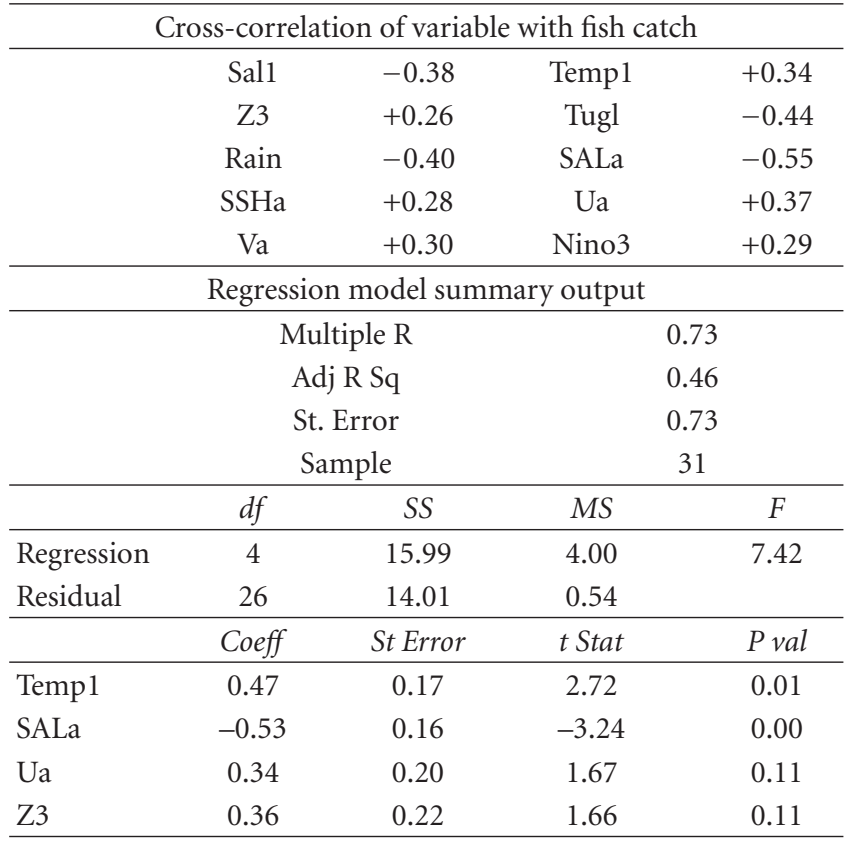

a key influence. The composite fields gave evidence of an anomalous conveyor belt that favours the migration of juvenile fish from west to south coast. Further work can be directed towards biochemical forcing using ocean reanalysis data on water chemistry and chlorophyll, intraseasonal analyses of recent years with better data, and separation of environmental responses per fish species.

\section{Acknowledgments}

The data used here were extracted from websites of the Food and Agricultural Organization, International Research Institute for Climate, the National Center for Environmental Prediction, and the Climate Explorer of the Netherlands Meteorological Institute.

\section{References}

[1] D. Lluch-Belda, R. Crawford, T. Kawasaki et al., "Worldwide fluctuations of sardine and anchovy stock. The regime problem," African Journal of Marine Science, vol. 8, pp. 195-205, 1989.

[2] D. Lluch-Belda, R. A. Schwartzlose, R. Serra et al., "Sardine and anchovy regime fluctuations of abundance in four regions of the world oceans: a workshop report," Fisheries Oceanogaphy, vol. 1, no. 4, pp. 339-347, 1993.
[3] H. A. Regier and J. D. Meisner, "Anticipated effects of climate change on freshwater fishes and their habitat," Bulletin of the American Fisheries Society, vol. 15, pp. 10-15, 1992.

[4] A. Bakun, "Global climate change and intensification of coastal ocean upwelling," Science, vol. 247, no. 4939, pp. 198201, 1990.

[5] A. Bakun, Ocean Processes and Marine Population Dynamics, California Sea Grant and Centro de Inesigationes Biologicas, La Paz, Mexico, 1996.

[6] M. H. Glantz, "Does history have a future? Forecasting climate change effects on fisheries by analogy," Fisheries, vol. 15, no. 6, pp. 39-45, 1990.

[7] T. Kawasaki, "Climate-dependent fluctuations in Far Eastern Sardine Population and their impacts on fisheries and society," in Climate Variability, Climate Change and Fisheries, M. Glantz, Ed., pp. 325-355, Cambridge University Press, 1992.

[8] T. Kawasaki, "Mechanisms governing fluctuations in pelagic fish populations," in Benguela trophic Functioning. South African Journal of marine Sciences, A. Paine et al., Ed., vol. 12, pp. 873-879, 1992.

[9] T. Kawasaki, "A decade of the regime shift of small pelagics. FAO expert consultation (1983) to the PICES III (1994)," Bulletin of the Japanese Society of Fisheries Oceanography, vol. 58, pp. 321-333, 1994.

[10] R. J. Beamish, D. J. Noakes, G. A. McFarlane, L. Klyashtorin, V. V. Ivanov, and V. Kurashov, "The regime concept and natural trends in the production of Pacific salmon," Canadian Journal of Fisheries and Aquatic Sciences, vol. 56, no. 3, pp. 516-526, 1999.

[11] FAO, "Chronicles of Marine fishery landings (1950-1994) Trend analysis and fisheries potential," Fisheries Technical Paper 359, Food and Agriculture Organization of the United Nations, Rome, Italy, 1996.

[12] FAO, Review of the State of World Fishery Resources: Marine Fisheries (by Marine Resources Service, Fishery Resources Division, Fisheries Department). Fisheries Circular 920, Food and Agriculture Organization of the United Nations, Rome, Italy, 1997.

[13] G. D. Sharp, J. Csirke, and S. Garcia, "Modeling fisheries: what was the question?" in Proceedings of the Expert Consultation to Examine the Changes in Abundance and Species Composition of Neritic Fish Resources, G. D. Sharp and J. Csirke, Eds., pp. 1177-1224, FAO Fisheries Report, 1983.

[14] M. E. Schlesinger and N. Ramankutty, "An oscillation in the global climate system of period 65-70 years," Nature, vol. 367, no. 6465, pp. 723-726, 1994.

[15] L. Klyashtorin and B. Smirnov, "Climate-dependent salmon and sardine stock fluctuations in the North Pacific," in Climate Change and Northern Fish Populations, R. Beamish, Ed., vol. 121, pp. 687-689, Canadian Special Publications Fisheries Aquatic Sciences, 1995.

[16] L. Klyashtorin and N. Sidorenkov, "Long-term climatic change and pelagic fish stock fluctuations in the Pacific," Reports of $\mathrm{Pa}$ cific Research Instuite of Fisheries and Oceanography, vol. 119, pp. 33-54, 1996.

[17] L. B. Klyashtorin, "Long-term climate change and main commercial fish production in the Atlantic and Pacific," Fisheries Research, vol. 37, no. 1-3, pp. 115-125, 1998.

[18] S. Minobe, "A 50-70 year climatic oscillation over the North Pacific and North America," Geophysical Research Letters, vol. 24, no. 6, pp. 683-686, 1997.

[19] M. R. Jury, W. B. White, and C. J. C. Reason, "Modelling the dominant climate signals around southern Africa," Climate Dynamics, vol. 23, no. 7-8, pp. 717-726, 2004. 
[20] A. Bakun and K. Broad, Climate and Fisheries: interacting paradigms, scales, and policy approaches. The IRI-IPRC Pacific Climate-Fisheries Workshop Honolulu, 2001.

[21] P. Lehodey, J. Alheit, M. Barange et al., "Climate variability, fish, and fisheries," Journal of Climate, vol. 19, no. 20, pp. 5009-5030, 2006.

[22] R. A. Schwartzlose, J. Alheit, A. Bakun et al., "Worldwide largescale fluctuations of sardine and anchovy populations," South African Journal of Marine Science, no. 21, pp. 289-347, 1999.

[23] R. H. Parrish, F. B. Schwing, and R. Mendelssohn, "Midlatitude wind stress: the energy source for climatic shifts in the North Pacific Ocean," Fisheries Oceanography, vol. 9, no. 3, pp. 224-238, 2000.

[24] J. J. Agenbag, A. J. Richardson, H. Demarcq, P. Fréon, S. Weeks, and F. A. Shillington, "Estimating environmental preferences of South African pelagic fish species using catch size- and remote sensing data," Progress in Oceanography, vol. 59, no. 2-3, pp. 275-300, 2003.

[25] M. R. Jury, "Tropical South-East Atlantic response to ENSO as an ecosystem indicator for the southern Benguela," African Journal of Marine Science, vol. 28, no. 1, pp. 41-50, 2006.

[26] D. B. Lluch-Cota, S. Hernández-Vázquez, and S. E. LluchCota, Empirical Investigation on the Relationship between Climate and Small Pelagic Global Regimes and El Niño-Southern Oscillation (ENSO). FAO Fisheries Circular 934, FAO, Rome, Italy, 1997.

[27] F. P. Chavez, J. Ryan, S. E. Lluch-Cota, and C. M. Ñiquen, "Climate: from anchovies to sardines and back: multidecadal change in the Pacific Ocean," Science, vol. 299, no. 5604, pp. 217-221, 2003.

[28] Y. M. Tourre, S. E. Lluch-Cota, and W. B. White, "Global multi-decadal ocean climate and small-pelagic fish population," Environmental Research Letters, vol. 2, no. 3, Article ID 034005, 2007.

[29] K. E. Trenberth and J. W. Hurrell, "Decadal coupled atmosphere-ocean variation in the North Pacific Ocean," in Climate Change and Northern Fish Populations, R. Beamish, Ed., vol. 121, pp. 14-24, Canadian Special Publications Fisheries Aquatic Sciences, 1995.

[30] N. J. Mantua, S. R. Hare, Y. Zhang, J. M. Wallace, and R. C. Francis, "A Pacific inter-decadal climate oscillation with impacts on salmon production," Bulletin of the American Meteorological Society, vol. 78, no. 6, pp. 1069-1079, 1997.

[31] L. V. Shannon, "The Benguela ecosystem, Part I. Evolution of the Benguela: physical features and processes," Oceanography and Marine Biology, vol. 23, pp. 105-182, 1985.

[32] L. Hutchings, M. Barange, S. F. Bloomer et al., "Multiple factors affecting South African anchovy recruitment in the spawning, transport and nursery areas," South African Journal of Marine Science, no. 19, pp. 211-225, 1998.

[33] C. D. van der Lingen, L. J. Shannon, and P. Cury, "Resource and ecosystem variability, including regime shifts, in the Benguela Current system," in Benguela: Predicting a Large Marine Ecosystem, L. V. Shannon, G. Hempel, P. Malanotte-Rizzoli, C. Moloney, and J. Woods, Eds., pp. 147-185, Elsevier, 2006.

[34] L. V. Shannon and G. Nelson, "The Benguela: large scale features and processes and system variability," in The South Atlantic: Present and Past Circulation, G. Wefer, W. H. Berger, G. Siedler, and D. J. Webb, Eds., pp. 163-210, Springer, Heidelberg, Germany, 1996.

[35] C. Roy, C. D. van der Lingen, J. C. Coetzee, and J. R. E. Lutjeharms, "Abrupt environmental shift associated with changes in the distribution of Cape anchovy Engraulis encrasicolus spawners in the southern Benguela," African Journal of Marine Science, vol. 29, no. 3, pp. 309-319, 2007.

[36] A. MacCall, "Sardine Regimes and mesoscale flow structure," in Climate and Fisheries: Interacting Paradigms, Scales, and Policy Approaches, A. Bakun and K. Broad, Eds., The IRI-IPRC Pacific Climate-Fisheries Workshop Honolulu, 2001.

[37] E. Kalnay, M. Kanamitsu, R. Kistler et al., "The NCEP/NCAR 40-year reanalysis project," Bulletin of the American Meteorological Society, vol. 77, no. 3, pp. 437-471, 1996.

[38] J. A. Carton and B. S. Giese, "A reanalysis of ocean climate using Simple Ocean Data Assimilation (SODA)," Monthly Weather Review, vol. 136, no. 8, pp. 2999-3017, 2008.

[39] H. Demarcq, R. Barlow, and L. Hutchings, "Application of a chlorophyll index derived from satellite data to investigate the variability of phytoplankton in the Benguela ecosystem," African Journal of Marine Science, vol. 29, no. 2, pp. 271-282, 2007.

[40] C. Torrence and G. P. Compo, "A practical guide to wavelet analysis," Bulletin of the American Meteorological Society, vol. 79, no. 1, pp. 61-78, 1998.

[41] M. R. Jury, "A thermal front within the marine atmospheric boundary layer over the Agulhas Current south of Africa: composite aircraft observations," Journal of Geophysical Research, vol. 99, no. 2, pp. 3297-3304, 1994.

[42] M. R. Jury, "A review of the meteorology of the eastern Agulhas Bank," South African Journal of Science, vol. 90, no. 3, pp. 109113, 1994.

[43] D. L. Covey and S. Hastenrath, "The Pacific El Niño phenomenon and the Atlantic circulation," Monthly Weather Review, vol. 106, pp. 1280-1287, 1978.

[44] D. B. Enfield and D. A. Mayer, "Tropical atlantic sea surface temperature variability and its relation to El Niño-Southern Oscillation," Journal of Geophysical Research C, vol. 102, no. 1, pp. 929-945, 1997.

[45] M. R. Jury, H. Mulenga, and H. Rautenbach, "Tropical Atlantic variability and indo-Pacific ENSO: statistical analysis and numerical simulation," Global Atmosphere and Ocean System, vol. 7, no. 2, pp. 107-124, 2000.

[46] M. J. Roberts and W. H. H. Sauer, "Environment: the key to understanding the South African chokka squid life cycle and fishery?" Antarctic Science, vol. 6, pp. 249-258, 1994.

[47] E. H. Schumann, A. L. Cohen, and M. R. Jury, "Coastal sea surface temperature variability along the south coast of South Africa and the relationship to regional and global climate," Journal of Marine Research, vol. 53, no. 2, pp. 231-248, 1995. 

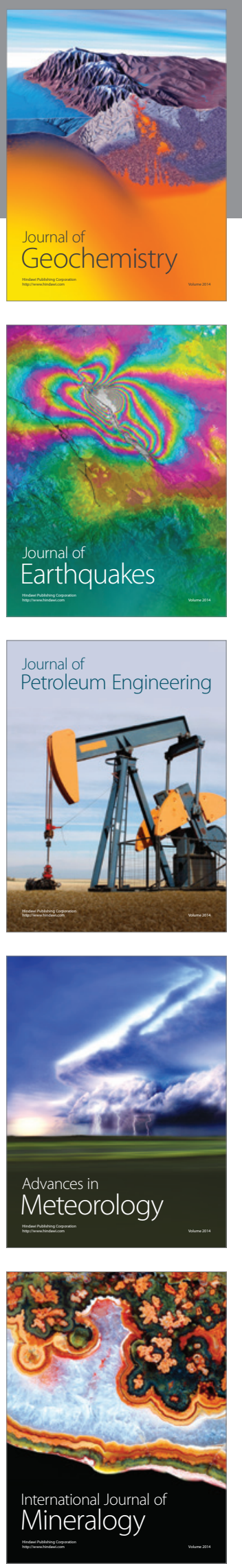
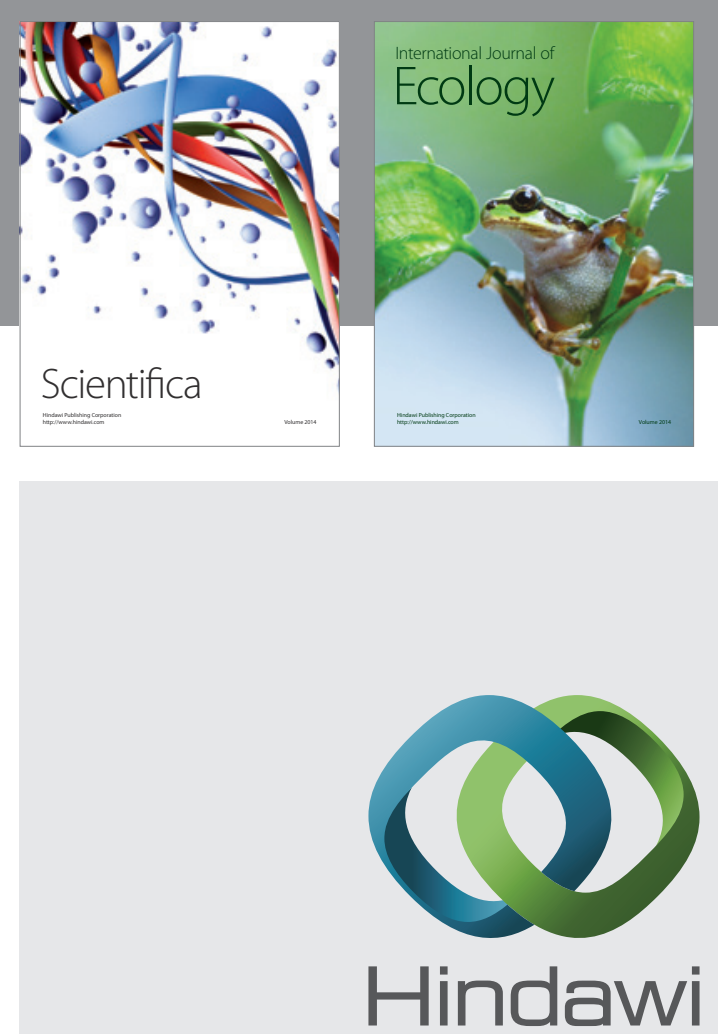

Submit your manuscripts at http://www.hindawi.com
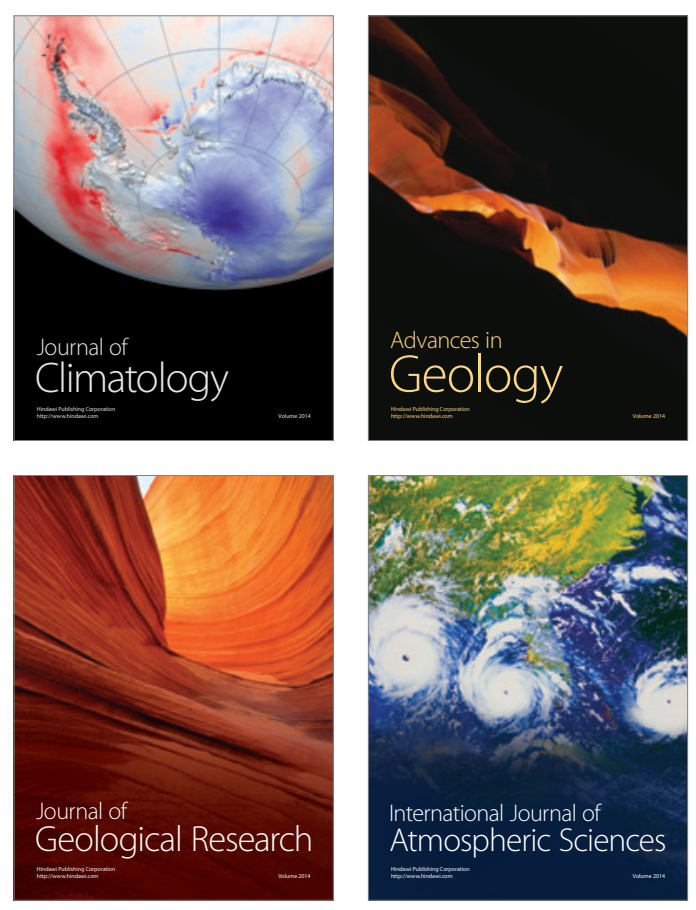
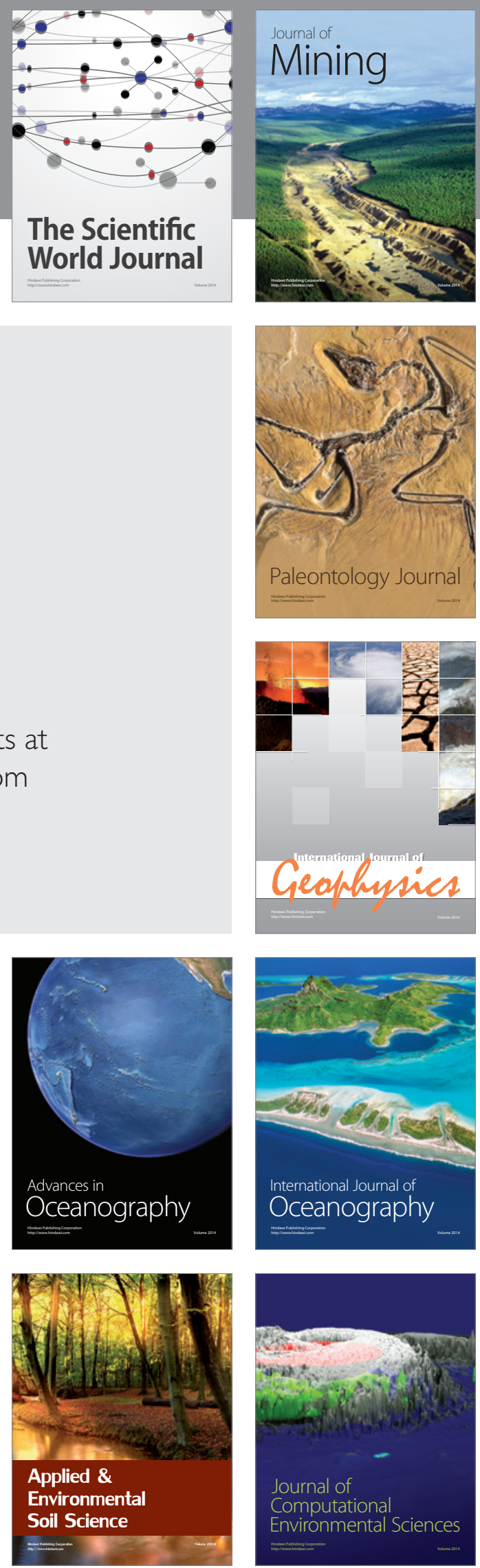